\title{
Contribution for Improvement of Visitor Monitoring in the Tatra National Park
}

\author{
Juraj Šrajda
}

Keywords: visitor monitoring, counting device, carrying capacity, weather, Tatra National Park

\section{Abstract}

The aim of this paper is to contribute to improving visitor monitoring in the Tatra National Park, based on the results obtained from the pilot use of a counting device. A direct data collection method was applied in order to monitor the number of visits. In the study period from May 31, 2008, to November 20, 2008, a counting device with pyroelectric detector (Eco Twin) registered the exact number of tourists entering the specified sector of the hiking trail that leads from the crossing near Žabí brook to Rysy peak. During the total observation period, the system registered 96366 traverses. As a result, an average daily volume of visits and a total volume of visits for the selected trail segment were identified. Temporal changes in the intensity of recreational use on a weekly and daily basis were observed for the period from June to October 2008 as well as the acceptance by visitors of seasonal trail closure. The current number of visitors was related to the specified carrying capacity of the trail and the impact of weather on the number of visitors was also taken into account. For the next period, we suggested further lines of investigation. Extension and improvement of research in this area is urgently needed because the amount and dynamics of visits to the Tatra mountains has changed in recent years. This might have an impact on the environment of the national park and biosphere reserve. The management will have to take this fact into account.
Profile

Protected area

Tatra National Park

Mountain range

Carpathians

Country

Slovakia

\section{Introduction}

In the sense of a new paradigm for protected areas, the expected continuing growth in visits and deepening conflicts in many natural sites call out for better management of visitor flows in those areas (Sheppard 2006). It is estimated that visits to Tatra National Park have increased hundredfold since its inception (Pacl 1989). This fact indicates the importance of visitor monitoring in the Tatra mountains.

There are several examples of long-term monitoring campaigns in protected areas worldwide, applying different data collection techniques (Rupf et al. 2008; Arnberger et al. 2005; Rauhala et al. 2002; Brandenburg 2001). Recently, automatic counting devices as well as video observations have been reported to be useful for collecting continuous data on visitor numbers (Cessford \& Muhar 2003). It is argued that simultaneous application of various techniques is desirable in order to gain a comprehensive understanding of public use at a given setting, for instance a combination of counting methods and survey techniques $(\mathrm{Mu}-$ har et al. 2002; Melville \& Ruohonen 2004). Increasing recreational use of national parks and protected areas can impact on natural and cultural resources and the quality of the visitor experience. How much recreational use can ultimately be accommodated in a park or protected area is often determined via the concept of carrying capacity (Manning 2002). Some of the re-

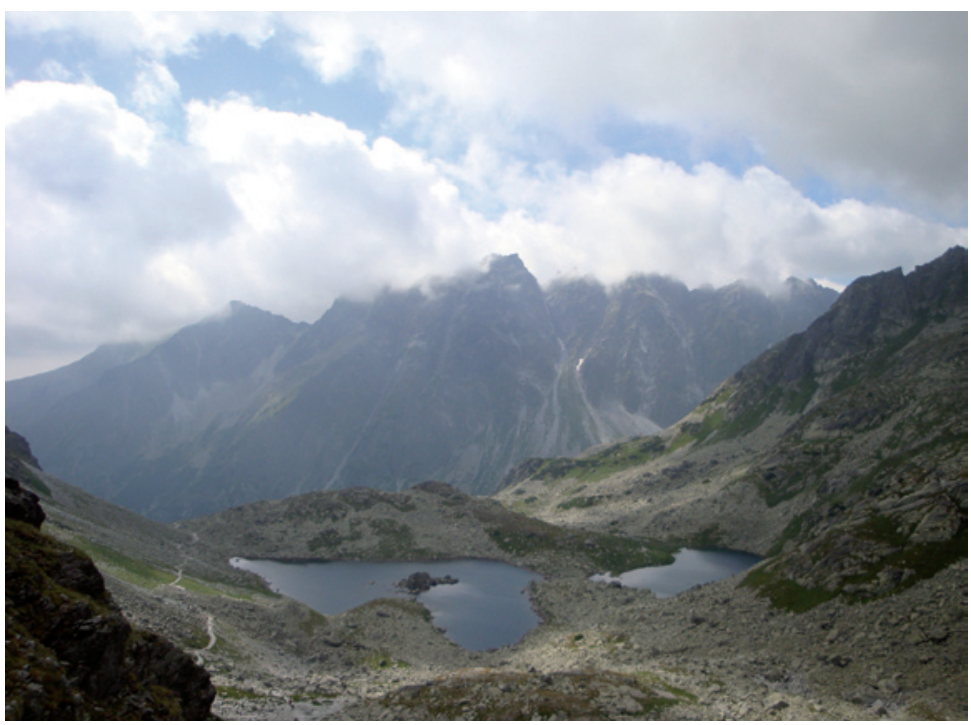

Tatra National Park (TNP), Slovakia

cent studies also propose modelling visitor flows in the context of weather and outdoor recreation (Brandenburg \& Ploner 2002).

The procedure of regular monitoring of visitor numbers of high-elevation environs in the Tatra mountains is described in detail by Šturcel (1990). The Administration of the Tatra National Park has provided an observation of frequency in the alpine environment of the park for some days of the summer tourist season since 1972 (monitoring of visitors between 5 a.m. and 


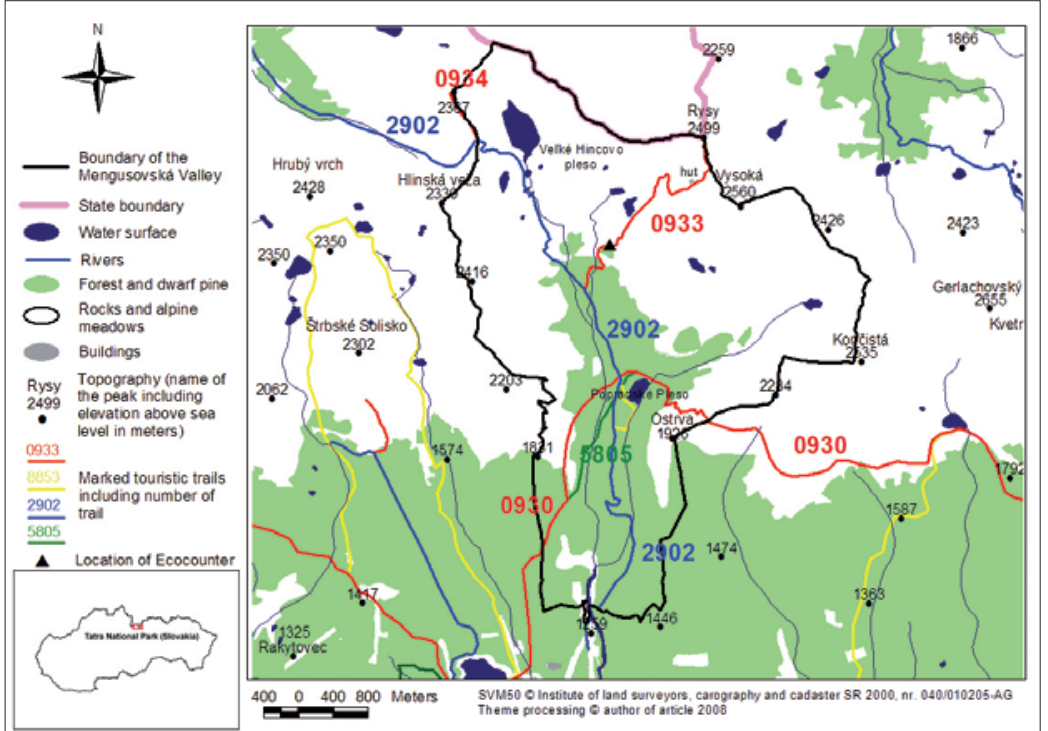

Figure 1 - Study area (TNP, Slovakia) and location of the Ecocounter on the monitored biking trail in the Mengusouská valley

7 p.m. including weather and nationality in 39 counting sites). However, the area of the National Park lacks a systematic long-term monitoring system of recreational use which would provide basic information about visiting rates at the most popular destinations of the National Park. The aim of this study was to make a contribution to improving visitor monitoring in the Tatra National Park, based on the results obtained from a pilot use of a counting device. In our study area we aimed to ascertain and / or investigate:

- average daily and total visits on the specified trail segment for particular days;

visit rate dynamics for particular days and hours in the period from June to October;

visitor acceptance of seasonal trail closure;

the current number of visitors in relation to the specified carrying capacity of the trail;

the impact of weather on the number of visitors.

\section{The study area}

The study area (Figure 1) is located in the Tatra National Park in the northern part of Slovakia on the bor-

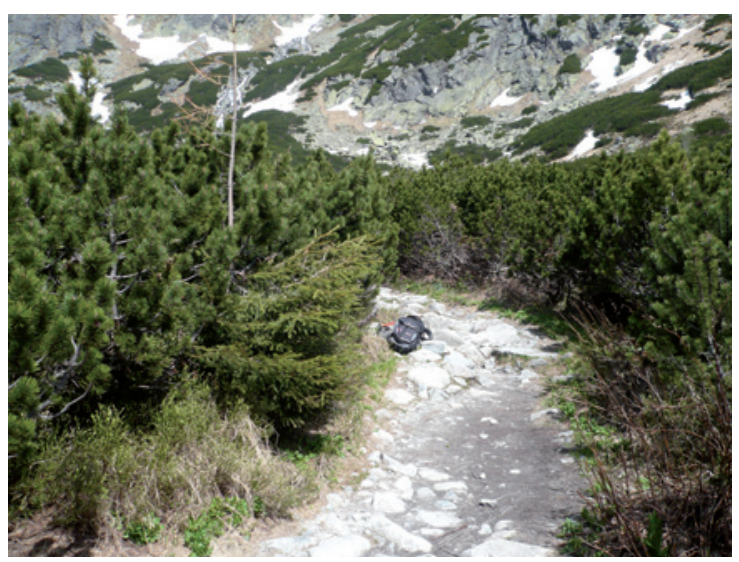

Figure 2 - Photograph of monitored hiking trail segment der with Poland $\left(49^{\circ} 05^{\prime}-49^{\circ} 20^{\prime} \mathrm{N}, 19^{\circ} 35^{\prime}-20^{\circ} 25^{\prime} \mathrm{E}\right.$; elevation 610 to $2656 \mathrm{~m}$ ). The monitored hiking trail is situated in the Mengusovská valley, which is a national nature reserve of $1612 \mathrm{ha}$. It is shaped like an irregular triangle tapering in the south. It is a valuable area of the Eastern Tatra mountains with presence of crystalline schist in a granodiorite massif, wellpreserved reef ridge relief and a surface modelled by a glacier. According to data from a booklet by the national nature reserve, the valley is full of complex ecosystems (valuable phyto- and zoocoenosis), which are typical for the Carpathians, with numerous tarns (the largest and deepest tarn on the Slovak side of the Tatra mountains is Velké Hincovo). There is abundant presence of endemic, critically endangered and precious species of vertebrates and invertebrates. The high-elevation region is preserved by functioning selfregulating mechanisms. In many locations (Popradské tarn, Ostrva, Hincovo tarn, Rysy), however, there is a very negative impact of tourism. The area belongs to a biocentre of transregional significance and to a bilateral national park as well as to a biosphere reserve. The Mengusovská valley is considered one of the most beautiful valleys of the Tatra mountains. It features the symbolic cemetery for the victims of the Tatra mountains (near Popradské tarn and hut) as well as the highest-situated hut in the Tatra mountains under the Rysy peak. The area is adjacent to other reserves with the highest degree of protection. The state of protection as a summary of all impacts affecting the ecosystems is influenced partly negatively by touristic utilization.

The monitored hiking trail no. 0933 , marked in red, see Figure 1, leads from the crossing near Žabí brook to the Rysy peak in the Mengusovská valley (Figures 1,2) in elevation from 1560 to $2500 \mathrm{~m}$. Total length of the trail is $4.8 \mathrm{~km}$ with a great and very steep slope. The visitors on the trail are monitored during regular monitoring of visitor numbers (Šturcel 1990). Visits to the trail usually peak during the International Youth Gathering to climb Rysy peak on the first August weekend. The trail (like the other 36 trails) is seasonally closed between November 1 and June 15 for reasons of nature protection and tourist safety. The visitor charter of the national park also prohibits night movement on the trails. The area was already evaluated by many authors in terms of carrying capacity (Midriak 1989; Drdoš 1989; Šoltés \& Šoltésová 1989).

\section{Methods}

In order to address the objectives of the study, a direct data collection method was used to monitor visitor numbers in the selected test area (Muhar et al. 2002). In the period from May 31, 2008, to November 20, 2008 , a counting device with pyroelectric detector, the Eco Twin, registered exact numbers of tourists who entered the specified sector of the hiking trail. Pyroelectric technology and optical counting technologies 


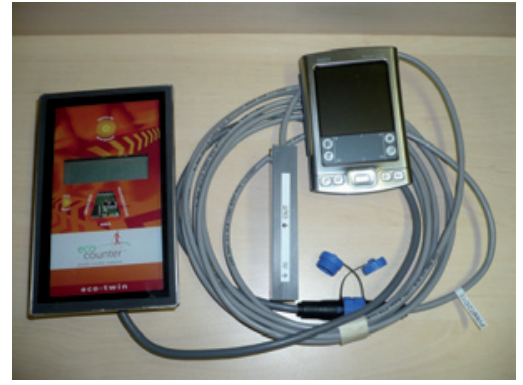

Figure 3 - Monitoring equipment (pyroelectric sensor, data logger and palmtop)

in general must comply with stricter installation requirements than other types of sensors. So installation of our counting device strictly followed the relevant instructions. Cessford et al. (2002) states advantages and disadvantages of counting devices. The reported advantages of the mechanism are precision (marginal error limited to $\pm 5 \%$ ), inconspicuous installation in the terrain (prevention of vandalism), self-action (lifetime of batteries 10 years), water-resistance (material resistant towards extreme impacts), undemanding installation and service, and simple use. In this case, we used a pyroelectric detector for walkers (Figure 3). A lens sensitive for the infrared radiation emitted by the human body detects each person who passes. The narrowness of the counting area means that the device can count two people following each other closely. It is possible to determine the direction of the hiker with the Eco-Twin logger. The Pyro range developed by the Eco-counter R\&D service is particularly efficient in avoiding false counts generated by vegetation movement, rain or sun. Every passage is analysed at four points using a sophisticated algorithm. Results are stored in the Eco Logger. Data is collected on a PDA Palmtop Tungsten E2 via an infra-red link. Eco-PC software was used for data processing. The visitor distribution over time was analysed and the counted persons were related to carrying capacity (Manning 2002) and weather data (Brandenburg \& Ploner 2002).

\section{Results}

During the total monitoring period (174 days), the system registered 96366 traverses in both directions (50292 in, 46074 out). Higher number of traverses into the valley may be explained by visitors continuing to the Polish side after reaching Rysy peak, which is especially popular with Polish tourists (highest peak in Poland). The maximum number of visitors counted in both directions in the trail was registered on Saturday, September 13, 2008, with 2512 people (Figure 4). This was not only due to suitable weather conditions but also thanks to a busy bank holiday weekend on both sides of the border (Monday was a bank holiday, September 15 is a national holiday). Other graphs presented here (Figures 5,6) show highest numbers of visits in August and higher numbers of visits at weekends and in the middle of the week.

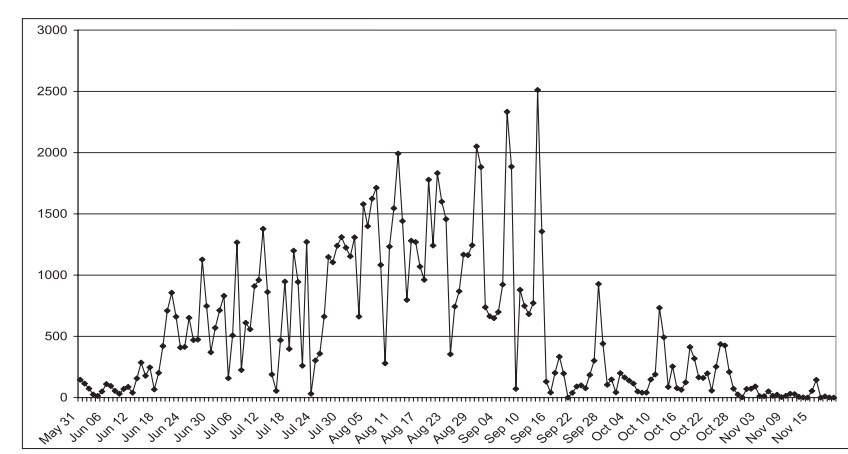

Figure 4-Seasonal dynamics of visits in both directions on the monitored biking trail during the period 31/05/2008-20/11/2008

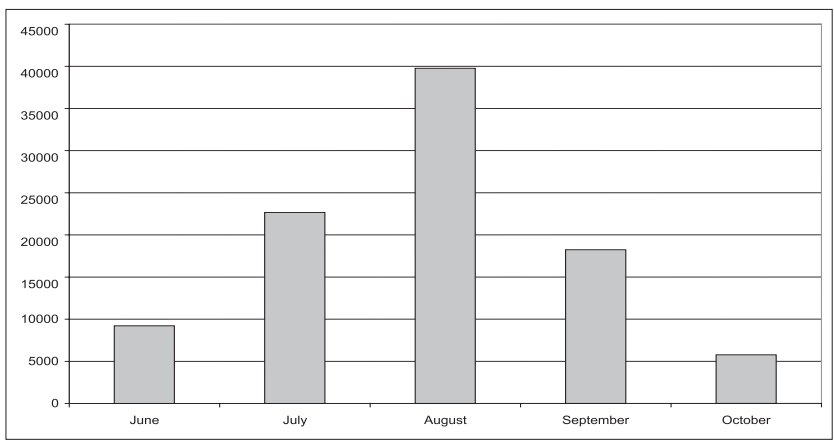

Figure 5 - Monthly dynamics of visits in both directions on the monitored biking trail between June and October 2008

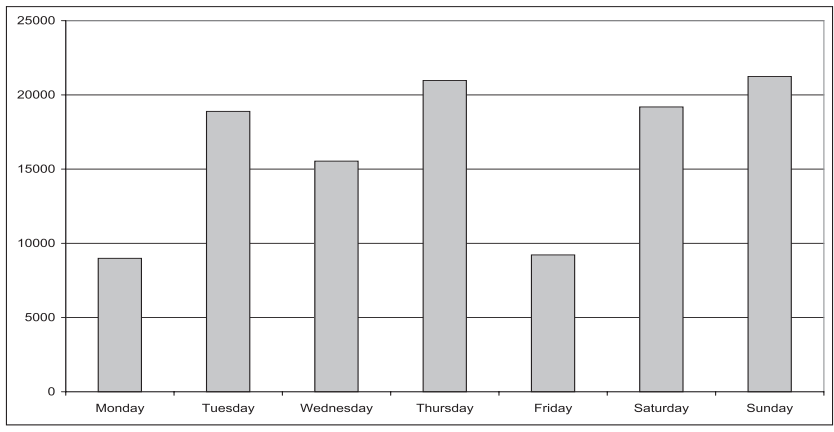

Figure 6 - Visit dynamics of weekdays in both directions on the monitored hiking trail during July 2008

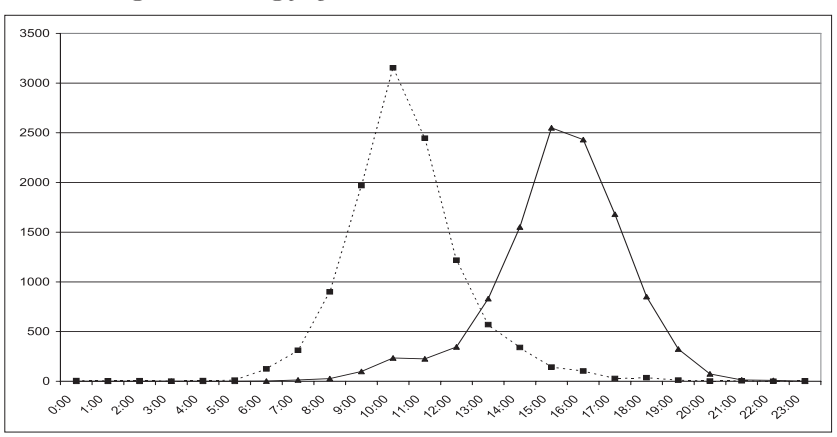

Figure 7 - Daily dynamics of visits on the monitored biking trail during July 2008 (dashed line - in, continuous line - out)

We can observe also daily dynamics (Figure 7 ) in the example of July 2008. Most people entered the valley before noon, about 10 a.m., and came back in the afternoon at 3 p.m.

For the demands of practical nature protection and ranger service, we should emphasize the lack of acceptance of the seasonal trail closure (e.g. May 31, 

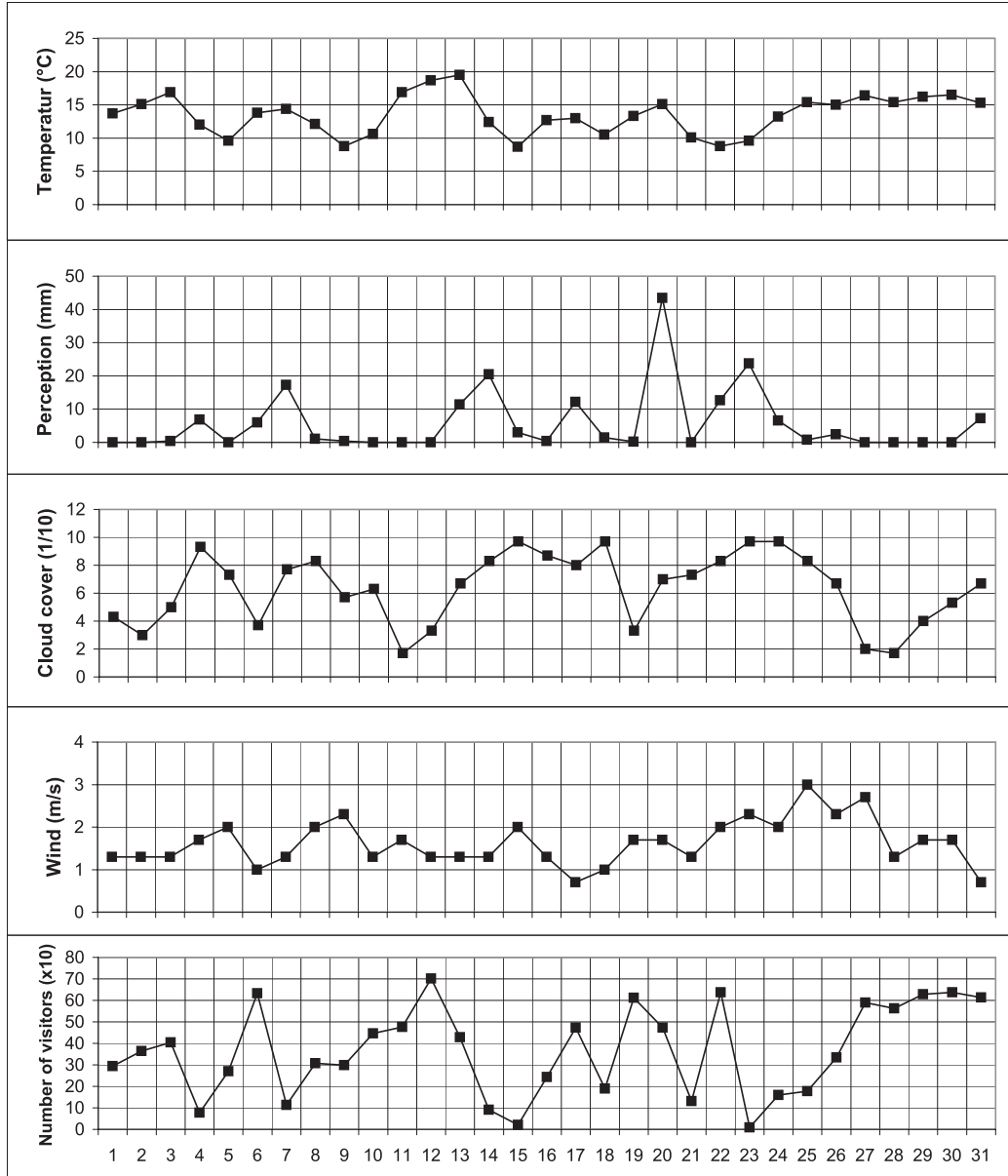

Figure 8 - Impact of the weather on visitor numbers during July 2008

2008: 146 traverses in both directions, and November 16, 2008: 145 traverses). Also in terms of established visiting regulations, we registered night hikers in the valley (e.g. August 4-5, 2008). These activities might have a direct negative impact on the protection of fauna (disturbance). Interpretation of this data can introduce methodological problems. However, during installation we tried to find a suitable position of the required measurement zone according to installation advice to prevent the detection of animals.

If we compare the current number of visitors to the hiking trail with the specified carrying capacity of the trail, we can detect a fiftyfold overload of the specified limit. The potential carrying capacity of a trail in terms of destruction of its surface or, more precisely, the geo-ecological carrying capacity should equal the average number of tourists per day of the summer season - up to 50 people according to Midriak (1989) or 63 people according to Drdoš (1989). Šoltés and Šoltésová (1989) state an average daily number of visitors for the monitored trail of 1990 people in both directions (994 towards the Rysy, 996 back from the Rysy). On the basis of an acceptable capacity, there was a proposal to decrease daily visits to $1 / 5$ (on average about 400 people per day in both directions). Stated discoveries confirm a continuing tendency of negative impact on the ground cover and flora due to an overload of visitors (Barančok \& Barančoková 2008).
Table 1 - Pearson correlation between weather conditions (temperature, precipitation, cloud, wind) and number of visitors

\begin{tabular}{|l|r|}
\hline & Number of visitors \\
\hline Temperature & 0.51657 \\
\hline Precipitation & -0.16894 \\
\hline Cloud cover & -0.69884 \\
\hline Wind & -0.21682 \\
\hline Number of visitors & 1 \\
\hline
\end{tabular}

The impact of weather on the number of tourists was also identified in the model area. Figure 8 shows data captured in July 2008 from the station Slovak Hydometeorological Institute Štrbské Pleso (average daily temperature, precipitation, cloud, wind speed). Looking at the number of visitors in July 2008, we can observe the impact of adverse weather on visits (e.g. Wednesday July 23, 2008). However, visitor numbers at weekends are generally high despite adverse weather (e.g. Sunday July 20, 2008). Table 1 shows how variables describing weather conditions are connected with the number of visitors (less cloudiness - more visitors, higher temperature - more visitors). Precipitation was not so highly correlated, because twice during the month there were fairly heavy rains on Sunday. But if weekends and working days were looked at separately, one could see also this dependency.

\section{Discussion and conclusion}

The paper shows pilot visitor monitoring using a direct counting method (pyroelectric sensor) of one hiking trail in the Tatra National Park. The visitor distribution over time was analysed and the counted persons were related to carrying capacity studies and weather data. The comparison with weather conditions is short and there is great potential for developing models for the connections between variables (Brandenburg \& Ploner 2002). Comparisons of visits with carrying capacity could also be worked out more precisely in the next period. As the automatic counting systems normally have some miscounts, it is strongly suggested that calibration be integrated in further investigations and possible error discussed (to control the results, e.g. night counts). Calibration with ensuing data correction is necessary to get precise visitor numbers. The collection of precise data is important because the study compares visitor data with those of the carrying capacity estimate as a basis for further recommendations to the management. Rupf et al. (2006 and 2008), on an example of automatic visitor counting with acoustic slab sensors in the Swiss National Park, showed possible difficulties and differences of up to $50 \%$. Calibration of the counting has to be done on site and not only as functional tests, as is also suggested by Ross (2005). These difficulties are even more severe if the authors deal with "in \& out visitor data".

Long-term monitoring of recreational use is necessary to gain a comprehensive picture of visitor flows in the protected area. In the Slovakian part of the 
Tatra mountains, neither entrance tickets nor permits are issued for national park visitors. Since 1972, estimates of visitor load in the national park were based on spot check visitor counting campaigns, conducted on selected days during a peak season at key locations in high-elevation environs of the national park. This study, thanks to the application of an automatic counter, enabling long-term observation of public use in the Mengusovská valley, revealed the highly dynamic character of visit levels. We observed daily and weekly changes of visitor load during the study period and identified certain relationships between meteorological conditions and visitor numbers. Long-term monitoring data provide new insights for the national park management. Better understanding of public use dynamics can support allocation of park rangers in the area, confirm investments needed for service and reparation of trails, prevent erosion and degradation, etc. After successful implementation of the counting station in the test area of the Mengusovská valley, we propose further activities to improve the results:

- installation of additional counters in the test area to obtain complete information on the spatial distribution of visitors within the area (where most people come from, how many of them reach the circular or the summit, utilization of the passage Rysy - Rysy from Poland, etc.);

- installation of other equipment (video camera) to identify access modes of transport of the tourists, more detailed structure of visitors as well as potential conflicts among them;

conducting a survey campaign (socio-demographic, psychographic and behavioural data, such as motives for visiting the national park, gender, education, age, nationality, permanent address, duration and regularity of visits, reaction of people to the high number of tourists - social stability, relationship to the national park, adequate expenditure).

Extension of research in this area is urgent because the number and dynamics of visits in the Tatra mountains seems to have changed in recent years. This might have an impact on the environment of the national park and biosphere reserve. Therefore management will have to adapt to the visits. Management of visitors, services and infrastructure is an essential part of the integrated management of protected areas. Studies of this kind can serve as a basis for high-quality management of the protected areas.

\section{Acknowledgements}

We are grateful to the American sister park Rocky Mountain and to the French company Eco-counter for support and sponsorship, and to the Slovak Hydrometeorological Institute, workstation Košice, for providing data and information. The author also wishes to thank Mária Uhrínová for her help with the translation and to Karolina Taczanovska for her valuable comments.

\section{References}

Arnberger, A., W. Haider \& C. Brandenburg 2005: Evaluating Visitor-Monitoring Techniques: A Comparison of Counting and Video Observation Data. Environmental Management 35, 4: 1-12.

Barančok, P. \& M. Barančoková 2008: Evaluation of the tourist path carrying capacity in the Belianske Tatry Mts. Ekológia (Bratislava) 27, 4: 401-420.

Brandenburg, C. 2001: Erfassung und Modellierung von Besuchsfrequenzen in Erholungs- und Schutzgebieten - Anwendungsbeispiel Nationalpark. Donau-Auen, Teilgebiet Lobau. Institut für Freiraumgestaltung und Landschaftspflege. Universität für Bodenkultur, Wien. Dissertation.

Brandenburg, C. \& A. Ploner 2002: Models to Predict Visitor Attendance Levels and the Presence of Specific User Group. In: Arnberger, A., C. Brandenburg \& A. Muhar (eds.), Monitoring and Management of Visitor Flows in Recreational and Protected Areas. Conference Proceedings: 166-172. Vienna.

Cessford, G., S. Cockburn \& M. Douglas 2002: Developing New Visitor Counters and their Applications for Management. In: Arnberger, A., C. Brandenburg \& A. Muhar (eds.), Monitoring and Management of Visitor Flows in Recreational and Protected Areas. Conference Proceedings: $14-20$. Vienna.

Cessford, G. \& A. Muhar 2003: Monitoring options for visitor numbers in national parks and natural areas. Journal for Nature Conservation 11, 4: 240-250.

Drdoš, J. 1989: Únosná návštevnost’ krajiny v TANAPe. Zbornike prác o TANAP 29: 191-237. In Slovak.

Manning, R.E. 2002: How Much is Too Much? Carrying Capacity of National Parks and Protected Areas. In: Arnberger, A., C. Brandenburg \& A. Muhar (eds.), Monitoring and Management of Visitor Flows in Recreational and Protected Areas. Conference Proceedings: 306-313.

Melville, S. \& J. Ruohonen 2004: The development of a remote-download system for visitor counting. In: Sievänen, T., J. Erkonnen, J. Jokimäki, J. Saarinen, S. Tuulentie \& E. Virtanen, (eds.), Policies, Methods and Tools for Visitor Management. Proceedings of The Second International Conference on Monitoring and Management of Visitor Flows in Recreational and Protected Areas, Rovaniemi: 37-43.

Midriak, R. 1989: Limity zat'aženosti turistických chodníkov v TANAPe so zretel'om na deštrukciu ich povrchu. Zborníkpráco TANAP 29: 239-251. In Slovak.

Muhar, A., A. Arnberger \& C. Brandenburg 2002: Methods for Visitor Monitoring in Recreational and Protected Areas: An Overview. In: Arnberger, A., C. Brandenburg \& A. Muhar (eds.), Monitoring and Management of Visitor Flows in Recreational and Protected Areas. Conference Proceedings: 1-6. Vienna.

Pacl, J. 1989: Návrh na štátne prírodné rezervácie v TANAPe z hydrologického hl’adiska. Zborník prác o TANAP 29: 59-79. In Slovak.

Rauhala, J., J. Erkkonen \& H. Iisalo 2002: Standardisation of Visitor Counting - Experiences from Finland. In: Arnberger, A., C. Brandenburg \& A. Muhar (eds.), 
Monitoring and Management of Visitor Flows in Recreational andProtected Areas. Conference Proceedings:258-263. Vienna.

Ross, J. 2005: Visitor counters in parks: management practice for counter calibration. Department of conservation. Wellington. New Zealand.

Rupf, R., F. Filli \& M. Wernli 2006: Visitor Counting with Acoustic Slab Sensors in the Swiss National Park. In: Siegrist, D., C. Clivaz, M. Hunziker \& S. Iten (eds.), Exploring the Nature of Management. Proceedings of the Third International Conference on Monitoring and Management of Visitor Flows in Recreational and Protected Areas. University of Applied Sciences Rapperswil, Switzerland, 13 - 17 September 2006: 72-77.

Rupf, R., M. Wernli \& R. Haller 2008: How to elaborate precise visitor numbers? In: Raschi A. \& S. Trampetti (eds.), Management for Protection and Sustainable Development, the Fourth International Conference on Monitoring and Management of Visitor Flows in Recreational and Protected Areas. Montecatini Terme, Italy, 14 - 19 October 2008: 161-164.

Sheppard, D. 2006: The New Paradigm for Protected Areas: Implications for Managing Visitors in Protected Areas. In: Siegrist, D., C. Clivaz, M. Hunziker \& S. Iten (eds.), Exploring the Nature of Management. Proceedings of the Third International Conference on Monitoring and Management of Visitor Flows in Recreational and Protected Areas. University of Applied Sciences Rapperswil, Switzerland, 13 - 17 September 2006: 33-45.

Šoltés, R., Šoltésová, A., 1989: Únosná kapacita okolia turistických chodníkov v TANAPe z hladiska vegetačného krytu. Zborník prác o TANAP 29: 253334. In Slovak.

Šturcel, M., 1990: Návštevnost' vysokohorského prostredia TANAPu. Zborník prác o TANAP 30: 163178. In Slovak.

\section{Author}

Juraj Švajda

MSc. Ing. Juraj Švajda, PhD., Institute of High Mountain Biology, University of Žilina, SK-059 56 Tatranská Javorina

svajda@uniza.sk

juraj.svajda@gmail.com 